\title{
Effect of supplementation with Escherichia coli phytase for broilers on performance, nutrient digestibility, minerals in the tibia and diet cost
}

\author{
Efeito da suplementação com fitase Escherichia coli para frangos de \\ corte sobre o desempenho, digestibilidade de nutrientes, minerais na \\ tíbia e custo da dieta
}

\author{
Gabriel Villela Dessimoni ${ }^{1 *}$; Nilva Kazue Sakomura²; Daniella Carolina Zanardo \\ Donato $^{2}$; Fábio Goldflus ${ }^{3}$; Nayara Tavares Ferreira ${ }^{4}$; Felipe Santos Dalólio ${ }^{5}$
}

\begin{abstract}
Although phytase has been researched, new enzymes have been produced, leading to different animal responses. In this scenario, the present study proposes to evaluate the inclusion of a bacterial phytase produced by Escherichia coli in broiler diets based on corn and soybean meal, with or without nutrient reductions, on the performance, nutrient digestibility, phosphorus bioavailability, and bone minerals of those animals and on the economic viability of this practice. A total of 896 male broiler chickens were distributed into 32 experimental units, each housing 28 broilers. The experiment was set up as a completely randomized design with four treatments (Positive Control (PC)- diet meeting the nutritional requirements of the broiler chickens; Negative Control (NC) with reductions of $100 \mathrm{kcal} / \mathrm{kg}$ of ME, $0.14 \%{ }_{\text {av }} \mathrm{P}$ and $0.11 \%{ }_{\mathrm{t}} \mathrm{Ca} ; \mathrm{NC}+$ phytase $(500 \mathrm{FTU} / \mathrm{kg}) ; \mathrm{PC}+$ phytase $\left.(500 \mathrm{FTU} / \mathrm{kg})\right)$ and 8 replicates. Phytase increased $(p<0.05)$ feed intake and body weight gain and improved feed conversion ratio in starter (1 to 21 days) and total ( 1 to 42 days) phases, respectively, compared with Negative Control diet without supplementation. The Negative Control + phytase diet also led to a feed intake similar to Positive Control in the starter and total phases. The inclusion of phytase without nutrient reductions improved $(p<0.05)$ feed conversion ratio in the starter phase, compared to Positive Control diet. There was an increase $(p<0.05)$ in the digestibility of dry matter, crude protein and phosphorus and in apparent digestible energy in the Negative Control + phytase diet compared to the Negative Control diet. Phytase supplementation increased $(p<0.05)$ the digestibility of crude protein, calcium and phosphorus, and apparent digestible energy compared to Positive Control diet. Ash, phosphorus, and calcium contents were higher in the Negative Control + phytase diet compared with those observed in the Negative Control diet without enzyme $(p<0.05)$. The Positive Control + phytase diet provided higher ash contents $(p<0.05)$, but calcium and phosphorus deposition was similar to those obtained with Positive Control diet. Phytase inclusion allows for a reduction in the diet cost per ton of produced feed. In conclusion, dietary supplementation with bacterial phytase produced from Escherichia coli for broiler chickens is recommended, as it provided increases in production performance, nutrient digestibility, and energy metabolizability and a reduction in the diet cost.
\end{abstract}

Key words: Bioavailability. Calcium. Exogenous enzyme. Phosphorus. Poultry production.

\footnotetext{
${ }^{1}$ Dr. em Zootecnia, Universidade Estadual Paulista Júlio de Mesquita Filho, UNESP, Jaboticabal, SP, Brasil. E-mail: gabdessimoni@ gmail.com

2 Prof ${ }^{\text {as }}$, UNESP, Jaboticabal, SP, Brasil. E-mail: sakomura@fcav.unesp.br; dzdonato@gmail.com

3 General Manager, Goldfeed Nutrição e Saúde Animal. Idaiatuba, SP, Brasil. E-mail: fabio.goldflus@goldfeed.com.br

4 Dra em Zootecnia, UNESP, Jaboticabal, SP, Brasil. E-mail: nayaratf@hotmail.com

5 Pós-Doutorando em Zootecnia, Universidade Federal dos Vales do Jequitinhonha e Mucuri, UFVJM, Diamantina, MG, Brasil. E-mail: felipesantos181@hotmail.com

* Author for correspondence
} 


\section{Resumo}

Embora a fitase tenha sido estudada, novas enzimas foram produzidas, levando a respostas animais diferentes. Nesse sentido, o presente estudo teve como objetivo avaliar a inclusão de fitase bacteriana produzida por Escherichia coli em dietas à base de milho e farelo de soja, com ou sem redução de nutrientes sobre o desempenho, digestibilidade dos nutrientes, biodisponibilidade de fósforo, minerais ósseos e viabilidade econômica. Foram distribuídos 896 frangos de corte machos em 32 unidades experimentais, cada unidade constituída por 28 frangos. O delineamento foi inteiramente casualizado com quatro tratamentos (Controle Positivo (CP) - dieta que satisfaz os requisitos nutricionais das aves; Controle Negativo $(\mathrm{CN})$ - reduções de $100 \mathrm{kcal} / \mathrm{kg} \mathrm{EM} ; 0,14 \%{ }_{\text {av }} \mathrm{P}$ e $\left.0,11 \% \mathrm{Ca}\right) ; \mathrm{CN}+$ fitase $(500$ FTU $/ \mathrm{kg}) ; \mathrm{CP}+$ fitase $(500 \mathrm{FTU} / \mathrm{kg}))$ e 8 repetições. A fitase aumentou $(\mathrm{p}<0,05)$ o consumo de ração, o ganho de peso médio e melhorou a conversão alimentar nas fases inicial (1 a 21 dias) e total (1 a 42 dias), respectivamente, em comparação com a dieta Controle Negativo, sem suplementação. O Controle Negativo + fitase também apresentou consumo de ração semelhante ao Controle Positivo nas fases inicial e total. A inclusão da fitase sem redução dos requerimentos nutricionais (Controle positivo + fitase) melhorou $(\mathrm{p}<0,05)$ a conversão alimentar na fase inicial, em comparação com a dieta Controle Positivo. Houve aumento na digestibilidade de matéria seca, proteína bruta, energia digestível aparente e fósforo, respectivamente, em Controle Negativo + fitase em comparação com a dieta controle negativo. A suplementação de fitase aumentou a digestibilidade de proteína bruta, energia digestível aparente, cálcio e fósforo, em comparação com a dieta de Controle Positivo. Os teores de cinzas, fósforo e cálcio foram maiores no Controle Negativo + fitase comparados com os da dieta Controle Negativo, sem enzima. No Controle Positivo + fitase observou-se maior teor de cinzas, mas a deposição de cálcio e fósforo foi semelhante em relação ao Controle Positivo. A inclusão da fitase permitiu redução nos custos da dieta/tonelada de alimento produzido. Em conclusão, recomenda-se a suplementação dietética com fitase bacteriana produzida por Escherichia coli para frangos de corte é recomendada, pois houve aumento no desempenho produtivo, maior digestibilidade e metabolizabilidade dos nutrientes e redução no custo das dietas.

Palvras-chave: Biodisponibilidade. Cálcio. Enzima exógena. Fósforo. Produção avícola.

\section{Introduction}

The high cost of inorganic phosphate has influenced the direction of research and the industry to discover alternative sources of phosphorus (P) or improve the availability of $\mathrm{P}$, for broilers. The phytase enzyme has been highlighted in the nutrition of non-ruminants as a tool to reduce the dietary inclusion of inorganic $\mathrm{P}$ and to decrease nutrient excretion through the excreta (WALDROUP et al., 2000; GRAÑA et al., 2013). With the growth and narrowing of an increasingly demanding market in terms of sustainability, poultry production has been under heavy pressure in the world, which has raised the importance of phytase. The phytase market generates billions of dollars per year (ADEOLA; COWIESON, 2011), creating many jobs directly or indirectly.
Corn and soybean meal contain a considerable amount of $\mathrm{P}$ present in the myo-inositol hexaphosphate complex molecule, which is a molecule formed by ionizable phosphate (NELSON; COX, 2014) that is capable of retaining cations, carbohydrates, microminerals, amino acids and some digestive enzymes (SEBASTIAN et al., 1998; SOHAIL; ROLAND, 1999; RAVINDRAN et al., 1999; SELLE; RAVINDRAN, 2007; COULIBALY et al., 2011). Because broiler chickens do not produce endogenous phytase to release this $\mathrm{P}$, the association between phytase and cereals generates a great potential for the release of these nutrients.

Although phytase has been researched, new enzymes have been produced, leading to different animal responses. The Escherichia coli-derived phytase is a 6-phytase because it hydrolyses the myo-inositol molecule at position 6 with a $\mathrm{pH}$ 
around 4.5 (RAGGON et al., 2008). In addition, it is highly stable in the gastro-intestinal tract of broilers. Proteolytic enzymes do not break phytase in the intestinal tract. Moreover, phytase works close to the optimal $\mathrm{pH}$ of pepsin (AUGSPURGER et al., 2003; PILLAI et al., 2006). However, its production incurs high costs and much water is spent in the process (PANDEY et al., 2001). Some studies have shown that supplementation with Escherichia coli-derived phytase improves performance, metabolizable energy, nutrient digestibility, as well as bone retention of $\mathrm{Ca}$ and $\mathrm{P}$ in birds (DILGER et al., 2004; ONYANGO et al., 2005; ADEOLA, 2010; RIBEIRO JUNIOR et al., 2016).

On these bases, the present study was undertaken to examine the inclusion of a phytase produced by Escherichia coli in broiler diets based on corn and soybean meal, with or without nutrient reductions on the performance, nutrient digestibility, phosphorus bioavailability, and bone minerals of those animals and on the economic viability of this practice.

\section{Materials and Methods}

The trial was conducted at the Laboratory of Poultry Sciences at the Department of Animal Science, Faculty of Agriculture and Veterinary Sciences - UNESP, located in Jaboticabal-SP, Brazil. All experimental procedures were approved by the Ethics Committee on Animal Use (CEUA 018760/14).

The broilers were housed in an experimental facility, with a tunnel-type system to control the environment. Temperature, humidity and air exchange were controlled automatically by exhaust fans and a climate control system, according to the age of the birds (COBB GUIDELINES, 2012). During the starter phase, incandescent lamps were used as a heating source according to the needs of poultry. Shavings litter, nipple drinkers and tubular feeders were used in all experimental plots. Infant tubular feeders were used until 14 days of age, which were then replaced by adult tubular feeders.
Water and feed were offered ad libitum during the entire trial period. The lighting program was set as $24 \mathrm{~h}$ of light daily. All birds were vaccinated with the challenge of the region: at the hatchery, against Marek and Gumboro diseases, and at 12 days of age, against New Castle, via water.

A total of 896 one-day-old Cobb 500 male chicks were weighed (46 $\pm 1 \mathrm{~g}$ each) and distributed into each treatment with similar mean body weights. The broilers were evaluated in a completely randomized design with four treatments and eight replicates, in which they were allocated to 32 pens $(1.0 \mathrm{x}$ $3.0 \mathrm{~m}$ ) that housed 28 chicks each. The following treatments were tested: Positive Control (PC) - diet meeting the nutritional requirements of the broiler chickens; Negative Control (NC) - reduction of $100 \mathrm{kcal} / \mathrm{kg}$ of metabolizable energy (ME), $0.14 \%$ available phosphorus $\left({ }_{\mathrm{av}} \mathrm{P}\right)$ and $0.11 \%$ total calcium $(\mathrm{Ca}) ; \mathrm{NC}+$ Phytase (500 FTU/kg), and PC + Phytase (500 FTU/kg).

The Positive Control diets were formulated to meet the nutritional requirements of broilers based on the recommendations of the Brazilian Tables for Poultry and Swine (ROSTAGNO et al., 2011). Table 1 describes the control diets and their nutritional compositions for the starter (1-14 days), grower (15-28 days) and finisher (29-42 days) phases. The phytase was produced by bacteria of the genus Escherichia coli (Phytafeed GR 5000G), by the Pintaluba Group (Reus, Spain).

Broilers and orts were weighed at 21 and 42 days of age. The following performance parameters were evaluated: feed intake, body weight gain, feed conversion ratio and viability. Mortality was recorded daily and was used to adjust the total number of broilers to determine feed intake and feed conversion ratio (SAKOMURA; ROSTAGNO, 2016).

Nutrient digestibility was determined based on the ileal digestibility, using a source of silica, (Celite) as a marker, which was added to all experimental diets at 14 days of age at $1 \%$. At 21 days of age, ten 
broilers from each experimental unit were chosen at random and slaughtered by electronarcosis followed by exsanguination. Immediately after slaughter, the ileum was exposed by an abdominal incision, and a segment of $20 \mathrm{~cm}$, which ends at 4 $\mathrm{cm}$ from the ileocecal junction, was removed and its contents were collected in a plastic container identified by treatment and replicate. The broilers were stimulated to consume feed four hours before slaughter to collect ileum intestinal contents.

Table 1. Composition and calculated nutritional values of Positive Control (PC) and Negative Control (NC) diets.

\begin{tabular}{lcccccc}
\hline \multirow{2}{*}{ Ingredient (\%) } & \multicolumn{2}{c}{$\mathbf{1}$ to 14 days } & \multicolumn{2}{c}{$\mathbf{1 5}$ to $\mathbf{2 1}$ days } & \multicolumn{2}{c}{$\mathbf{2 2}$ to $\mathbf{4 2}$ days } \\
\cline { 2 - 7 } & $\mathbf{P C}^{\mathbf{1}}$ & $\mathbf{N C}^{\mathbf{2}}$ & $\mathbf{P C}^{\mathbf{1}}$ & $\mathbf{N C}^{\mathbf{2}}$ & $\mathbf{P C}^{\mathbf{1}}$ & $\mathbf{N C}^{\mathbf{2}}$ \\
\hline Corn & 52.215 & 55.831 & 57.862 & 61.477 & 62.330 & 65.964 \\
Soybean Meal 45\% & 41.293 & 40.587 & 34.489 & 33.783 & 30.957 & 30.230 \\
Soy Oil & 2.865 & 0.500 & 2.911 & 0.546 & 3.460 & 1.089 \\
Limestone & 0.807 & 1.018 & 0.848 & 1.059 & 0.770 & 0.981 \\
Dicalcium Phosphate 18,5 & 1.707 & 0.942 & 1.563 & 0.798 & 1.223 & 0.458 \\
Salt & 0.431 & 0.429 & 0.426 & 0.425 & 0.399 & 0.397 \\
DL-Methionine 99\% & 0.289 & 0.285 & 0.308 & 0.304 & 0.260 & 0.256 \\
L-Lysine 98\% & 0.155 & 0.169 & 0.293 & 0.307 & 0.377 & 0.399 \\
L-Threonine 98\% & 0.038 & 0.040 & 0.100 & 0.102 & 0.064 & 0.066 \\
Mineral vitamin Premix ${ }^{3}$ & 0.200 & 0.200 & 0.200 & 0.200 & 0.160 & 0.160 \\
Market & - & - & 1.000 & 1.000 & - & - \\
Total & 100 & 100 & 100 & 100 & 100 & 100 \\
\hline & $\mathbf{N u t r i t i o n a l ~ l e v e l ~ ( \% ) ~}$ & & & \\
\hline Metabolizable Energy (kcal/kg) & 3000 & 2900 & 3050 & 2950 & 3170 & 3070 \\
Crude protein (\%) & 23.63 & 23.63 & 21.20 & 21.20 & 20.00 & 20.00 \\
Calcium (\%) & 0.881 & 0.771 & 0.841 & 0.731 & 0.717 & 0.607 \\
Available phosphorus (\%) & 0.436 & 0.296 & 0.401 & 0.261 & 0.335 & 0.195 \\
Phytic phosphorus (\%) & 0.240 & 0.244 & 0.227 & 0.232 & 0.224 & 0.228 \\
Sodium (\%) & 0.215 & 0.215 & 0.210 & 0.210 & 0.198 & 0.198 \\
Potassium (\%) & 0.916 & 0.914 & 0.808 & 0.806 & 0.757 & 0.754 \\
Digestible Methionine + cystine (\%) & 0.915 & 0.915 & 0.876 & 0.876 & 0.804 & 0.804 \\
Digestible Methionine (\%) & 0.611 & 0.609 & 0.598 & 0.595 & 0.536 & 0.534 \\
Digestible Lysine (\%) & 1.271 & 1.271 & 1.217 & 1.217 & 1.101 & 1.101 \\
Digestible Threonine (\%) & 0.826 & 0.826 & 0.791 & 0.791 & 0.715 & 0.715 \\
Digestible Tryptophan (\%) & 0.271 & 0.269 & 0.234 & 0.231 & 0.215 & 0.213 \\
\hline
\end{tabular}

${ }^{1} \mathrm{PC}=$ positive control (diet meeting the nutritional requirements of the broiler chickens); ${ }^{2} \mathrm{NC}=$ negative control (reduction of $100 \mathrm{kcal} / \mathrm{kg} \mathrm{ME} ; 0.14 \%{ }_{\text {av }} \mathrm{P}$ and $0.11 \% \mathrm{Ca}$; ${ }^{3}$ Folic acid $437.5 \mathrm{mg}$; Pantothenic Acid $6250 \mathrm{mg}$; Biotin $44 \mathrm{mg}$; Butylated hydroxyl toluene100 mg; Niacin 18750 mg; Selenium 187.5 mg; Vitamin A 4687500 IU; Vitamin B1 1250 mg; Vitamin B12 7500 mgc; Vitamin B2 3125 mg; Vitamin B6 1750 mg; Vitamin D3 1187500 IU; Vitamin E 17500 IU; Vitamin K3 940 mg; Manganese 44 g; Zinc $40.65 \mathrm{~g}$; Iron $31.25 \mathrm{~g}$; Copper $6250 \mathrm{mg}$; Iodine $625 \mathrm{mg}$; ${ }^{4}$ Source of silica - Celite $\left(100 \% \mathrm{SiO}_{2}\right)$. (Diets with phytase inclusion contained $100 \mathrm{~g} / \mathrm{t}(500 \mathrm{FTU} / \mathrm{kg})$. 
After collection, the digesta was frozen for later analysis. It was later thawed at room temperature and the samples were homogenized, weighed again, frozen and lyophilized at a temperature of $-80^{\circ} \mathrm{C}$ for $72 \mathrm{~h}$. After that, they were ground through an A11 basic analytical mill (IKA) and then sent to laboratory for analysis along with samples of the experimental diets.

The dry matter, gross energy, nitrogen, phosphorus, calcium, and acid insoluble ash (AIA) contents of the samples of digesta and diets were determined. Nitrogen was analyzed by the Kjeldahl method, while dry matter (final drying), calcium and phosphorus were determined by nitric-perchloric digestion (SILVA; QUEIROZ, 2009). For the determination of gross energy, the samples were pelleted and subjected to combustion in the bomb calorimeter. For the calculations of digestibility, AIA, the indigestible fraction present in diets and digesta was determined.

The digestibility of dry matter, crude protein, calcium and phosphorus and the apparent digestible energy were calculated based on the analysis of diets and ileal digesta, according to Sakomura and Rostagno (2016).

At 21 days of age, two birds from each experimental unit were sampled and their tibias were removed, placed in labeled plastic bags according to the pen and frozen. Once thawed, the tibias were stripped, identified and dried in a ventilated oven at $100^{\circ} \mathrm{C}$ for $24 \mathrm{~h}$. The excess fat was removed by immersing the tibias in ethyl ether until the total disappearance of fat. They were then dried in a ventilated oven again at $100^{\circ} \mathrm{C}$ for $24 \mathrm{~h}$. After that, the tibias were individually weighed on a precision scale and ground through a ball mill to determine the ash, calcium and phosphorus contents (SILVA; QUEIROZ, 2009).

Phosphorus bioavailability was calculated using the standard curve concept. To establish the standard curve, the intake of supplemental phosphorus (ISP) in Positive control and Negative control treatments was calculated according to the following equation: [ISP $(\mathrm{g})=\{($ Feed Intake $(\mathrm{g}) \times$ Supplemental dietary Phosphorus $(\%))\} / 100]$

Supplemental phosphorus was considered null in the most limiting treatment (Negative Control) and $0.14 \%$ for Positive Control, which was the difference in ${ }_{\text {av }} \mathrm{P}$ between Negative Control and the other treatments. The ISP was associated with the responses of performance (body weight gain) and bone-related (ash and phosphorus) variables to construct the standard curve. The results of performance and bone-related variables of the treatments with phytase addition were confronted with their respective standard curve to determine the total released phosphorus (RP) in grams. The equation below was used to obtain the nutritional matrix (bioavailability) of ${ }_{\text {av }} \mathrm{P}(\mathrm{BP})$ of the phytase enzyme, considering the feed intake (FI) of the broiler and the released phosphorus: BP $(\%)=\{\mathrm{RP}$ $(\mathrm{g}) / \mathrm{FI}(\mathrm{g})\} \times 100]$.

A cost analysis of the diets was performed to determine the economy of including phytase at different levels. For these calculations, were used data of phosphorus bioavailability, body weight gain and the dicalcium phosphate cost $(\mathrm{Y}=(4.865$ $\mathrm{x} \mathrm{A})$ - ( $\mathrm{I} \times \mathrm{B})$, where $\mathrm{Y}$ is the economic response in US\$/t; $A$ is the cost per kilogram of dicalcium phosphate; I is the inclusion of the enzyme in kilograms per ton and B is the cost of kilograms of phytase). Considering the bioavailability of phosphorus calculated based on the tibia $\mathrm{P}$, we have the following equation: $\mathrm{Y}=(6.270 \times \mathrm{A})-(\mathrm{I} \times \mathrm{B})$. The amount of inorganic dicalcium phosphate which could be replaced by phytase inclusion $(100 \mathrm{~g} / \mathrm{t}, 500$ FTU $/ \mathrm{kg}$ ) in the diet, based on the bioavailability found for this phytase inclusion, was calculated via linear equations taking into account the cost of the enzyme and of phosphate, as well as their addition, to obtain the best economic profit. The costs of dicalcium phosphate and enzyme (Phytafeed GR $5000 \mathrm{G}$ ) were quoted in the first quarter of 2015, as US\$ $0.50 / \mathrm{kg}$ and US $\$ 6.00 / \mathrm{kg}$, respectively. 
Data were analyzed by the general linear models procedure of SAS (2002). The errors in the statistical models were normally and independently distributed with constant variance. The viability variable was adjusted by ASEN (SQUARE ROOT (\%VIABILITY/100). Means were tested by the Student Newman Keuls - SNK multiple-range test at $5 \%$ of significance.
Results

\section{Performance}

The positive control and negative control diets affected $(p<0.05)$ feed intake, body weight gain and feed conversion ratio in the starter and total phases (Table 2). However, there was no effect $(p<0.05)$ on viability. The reduction of $\mathrm{ME}, \mathrm{Ca}$ and $\mathrm{P}$ led to decreases of 8.6 and $5.6 \%$ in feed intake, 12.3 and $9.9 \%$ in body weight gain, while feed conversion ratio increased by 5 and 8 points in the starter and total phases, respectively, in comparison to positive control diet.

Table 2. Effect of bacterial phytase produced by Escherichia coli on broiler performance.

\begin{tabular}{|c|c|c|c|c|}
\hline \multirow{2}{*}{ Treatment } & Feed Intake (g) & Body Weight Gain (g) & Feed Conversion Ratio (g/g) & ${\text { Viability }(\%)^{1}}^{1}$ \\
\hline & \multicolumn{4}{|c|}{ Starter (1 to 21 days) } \\
\hline $\mathrm{PC}^{2}$ & $1224^{\mathrm{A}}$ & $959^{\mathrm{A}}$ & $1.276^{\mathrm{B}}$ & 99.78 \\
\hline $\mathrm{NC}^{3}$ & $1119^{\text {в }}$ & $841^{\mathrm{C}}$ & $1.332^{\mathrm{D}}$ & 99.55 \\
\hline $\mathrm{NC}+$ Phytase & $1197^{\mathrm{A}}$ & $916^{\text {B }}$ & $1.307^{\mathrm{C}}$ & 99.78 \\
\hline PC + Phytase & $1222^{\mathrm{A}}$ & $974^{\mathrm{A}}$ & $1.255^{\mathrm{A}}$ & 99.78 \\
\hline $\mathrm{SEM}^{4}$ & 20 & 19 & 0.017 & 0.05 \\
\hline \multirow[t]{2}{*}{ p-value } & $<0.0001$ & $<0.0001$ & $<0.0001$ & 0.8871 \\
\hline & \multicolumn{4}{|c|}{ Total (1 to 42 days) } \\
\hline $\mathrm{PC}^{2}$ & $4954^{\mathrm{A}}$ & $3156^{\mathrm{A}}$ & $1.570^{\mathrm{A}}$ & 99.31 \\
\hline $\mathrm{NC}^{3}$ & $4675^{\text {в }}$ & $2845^{\text {в }}$ & $1.650^{\mathrm{C}}$ & 99.26 \\
\hline NC + Phytase & $4942^{A}$ & $3083^{\mathrm{A}}$ & $1.603^{\text {в }}$ & 97.92 \\
\hline PC + Phytase & $4912^{\mathrm{A}}$ & $3158^{\mathrm{A}}$ & $1.555^{\mathrm{A}}$ & 100.00 \\
\hline $\mathrm{SEM}^{4}$ & 104 & 68 & 0.011 & 0.09 \\
\hline p-value & 0.0001 & $<0.0001$ & $<0.0001$ & 0.2288 \\
\hline
\end{tabular}

${ }^{1}$ Mortality. Adjusted by ASEN (SQUARE ROOT (\%mortality/100)); ${ }^{2} \mathrm{PC}=$ positive control (diet meeting the nutritional requirements of the broiler chickens); ${ }^{3} \mathrm{NC}=$ negative control (reduction of $100 \mathrm{kcal} / \mathrm{kg} \mathrm{ME} ; 0.14 \%{ }_{\text {av }} \mathrm{P}$ and $0.11 \%{ }_{1} \mathrm{Ca}$ ); ${ }^{4} \mathrm{SEM}=$ Standard error of the means. ${ }^{\text {A-D }}$ Different letters in the same column differ by the SNK test $(p<0.05)$.

Supplementation with Escherichia coli phytase in the diet with nutrient reduction increased $(p<0.05)$ feed intake and body weight gain and improved feed conversion ratio in all phases. Phytase addition increased feed intake by 7.0 and $5.7 \%$, body weight gain by 8.9 and $8.4 \%$ and improved feed conversion ratio by 2 and 5 points in the starter and total phases, respectively, compared to negative control diet without phytase supplementation. The negative control + phytase treatment also provided a similar feed intake to positive control in the starter and total phases, and body weight gain also did not differ in the total phase. Phytase supplementation without nutrient reductions (Positive control + phytase) significantly affected $(p<0.05)$ feed conversion ratio in the starter phase. Feed conversion ratio was 
improved by 2 points compared to positive control diet without phytase supplementation.

\section{Digestibility}

Apparent digestible energy and $\mathrm{P}$ digestibility in negative control were lower compared to the results obtained with positive control treatment (Table 3). However, the digestibility of $\mathrm{Ca}$ was higher. There was a reduction of $113 \mathrm{kcal} / \mathrm{g}$ in the digestibility of energy (dry matter basis), a 5.3\% decreased in the coefficient of $\mathrm{P}$ digestibility and an increase of $17.3 \%$ in $\mathrm{Ca}$ digestibility in negative control compared to positive control diet.

Table 3. Effect of supplementation with bacterial phytase produced by Escherichia coli on nutrient digestibility in broilers at 21 days.

\begin{tabular}{|c|c|c|c|c|c|}
\hline Treatment & $\operatorname{DM}(\%)^{1}$ & $\mathrm{CP}(\%)^{2}$ & ADE (cal/g DM) ${ }^{3}$ & $\mathrm{Ca}(\%)^{4}$ & $P(\%)^{5}$ \\
\hline $\mathrm{PC}^{6}$ & $95.55^{\mathrm{AB}}$ & $82.50^{\text {B }}$ & $3376.5^{\mathrm{A}}$ & $54.82^{\mathrm{C}}$ & $60.97^{\text {B }}$ \\
\hline $\mathrm{NC}^{7}$ & $95.32^{\text {в }}$ & $82.59^{\text {в }}$ & $3263.8^{\text {в }}$ & $64.33^{\mathrm{A}}$ & $57.75^{\mathrm{C}}$ \\
\hline $\mathrm{NC}^{6}+$ Phytase & $95.90^{\mathrm{A}}$ & $83.99^{\mathrm{A}}$ & $3387.6^{\mathrm{A}}$ & $64.76^{\mathrm{A}}$ & $68.34^{\mathrm{A}}$ \\
\hline $\mathrm{PC}^{7}+$ Phytase & $95.80^{\mathrm{A}}$ & $84.60^{\mathrm{A}}$ & $3450.9^{\mathrm{A}}$ & $59.11^{\text {в }}$ & $68.58^{\mathrm{A}}$ \\
\hline $\mathrm{SEM}^{1}$ & 0.54 & 1.14 & 59.25 & 3.14 & 2.16 \\
\hline p-value & 0.014 & 0.0003 & $<0.0001$ & $<0.0001$ & $<0.0001$ \\
\hline
\end{tabular}

${ }^{1}$ Dry Matter Digestibility; ${ }^{2}$ Crude Protein Digestibility; ${ }^{3}$ Apparent Digestible Energy (dry matter basis); ${ }^{4}$ Calcium Digestibility; 5 Phosphorus Digestibility. ${ }^{6} \mathrm{PC}=$ positive control (diet meeting the nutritional requirements of the broiler chickens); ${ }^{7} \mathrm{NC}=$ negative control (reduction of $100 \mathrm{kcal} / \mathrm{kg}$ ME, $0.14 \% \mathrm{P}$ and $0.11 \% \mathrm{Ca}$ ); ${ }^{8} \mathrm{SEM}=$ Standard error of the means. ${ }^{\mathrm{A}-\mathrm{C}}$ Different letters in the same column differ by the SNK test $(p<0.05)$.

Inclusion of Escherichia coli phytase in the negative control diet increased $(p<0.05)$ dry matter digestibility, crude protein digestibility, apparent digestibility energy (dry matter basis) and $\mathrm{P}$ digestibility. However, there was no effect $(p<0.05)$ on $\mathrm{Ca}$ digestibility. The digestibility coefficients of dry matter, crude protein and P increased by $0.6 \%$, $1.7 \%$ and, $18.3 \%$, respectively while apparent digestible energy rose by $123 \mathrm{kcal} / \mathrm{g}$ (dry matter basis) compared to negative control diet. The negative control + phytase diet also increased the digestibility of crude protein, $\mathrm{Ca}$ and $\mathrm{P}$ compared to the positive control diet. Escherichia coli phytase supplemented without nutrient reductions increased the digestibility of crude protein $(0.3 \%), \mathrm{Ca}(7.8 \%)$ and $\mathrm{P}(12.5 \%)$ and apparent digestible energy (dry matter basis) (70 kcal/g) compared to positive control diet.

\section{Minerals in the tibia}

The reduction of $\mathrm{ME}, \mathrm{Ca}$ and $\mathrm{P}$ in the negative control diets was sufficient to ensure a low deposition of ash, $\mathrm{Ca}$ and $\mathrm{P}$ in the tibia of the broilers $(p<0.01)$ (Table 4). Ash, P and Ca were higher $(p<0.01)$ in the negative control + phytase treatment group when compared to those of the group fed negative control diet without phytase, but they were similar to those of positive control group. The positive control + phytase group showed higher ash contents, but $\mathrm{Ca}$ and $\mathrm{P}$ deposition was similar to that of positive control treatment.

\section{Bioavailability of phosphorus}

The $\mathrm{P}$ bioavailability for body weight gain (BWG), feed conversion ratio (FCR) and tibia mineral deposition (ash and $\mathrm{P}$ ) were calculated considering two increasing levels of $\mathrm{P}$ in the diets 
(Positive control $=1.71 \mathrm{~g}$ and Negative Control $=0)$. The fitted regression equation for BWG was $\mathrm{Y}=840.58+5.99 \mathrm{X}$, where " $\mathrm{X}$ " is the amount of phosphorus ( $\mathrm{g}$ ). For FCR, The fitted regression equation was $\mathrm{Y}=1.33-0.03 \mathrm{X}$, where " $\mathrm{X}$ " is the amount phosphorus (g). For bone ash, the fitted regression equation was $\mathrm{Y}=35.59+1.63 \mathrm{X}$, where
" $\mathrm{X}$ " is the amount phosphorus (g). The regression equation fitted for tibia $\mathrm{P}$ was $\mathrm{Y}=68.69+3.98 \mathrm{X}$, where " $\mathrm{X}$ " is the amount phosphorus (g). The linear regressions for $\mathrm{BWG}$ and tibia $\mathrm{P}$ had higher coefficients of determination $\left(\mathrm{R}^{2}=0.93\right.$ and 0.60$)$. Results pertaining to $\mathrm{P}$ bioavailability are shown in Table 5.

Table 4. Effect of supplementation with bacterial phytase produced by Escherichia coli on the tibia of broilers at 21 days.

\begin{tabular}{lccc}
\hline \multicolumn{1}{c}{ Treatment } & Ash (\%) & Phosphorus (mg/g of bone) & Calcium $(\mathbf{m g} / \mathbf{g}$ of bone) \\
\hline $\mathrm{PC}^{1}$ & $38.35^{\mathrm{B}}$ & $75.93^{\mathrm{A}}$ & $137.25^{\mathrm{A}}$ \\
$\mathrm{NC}{ }^{2}$ & $35.21^{\mathrm{C}}$ & $67.64^{\mathrm{B}}$ & $129.83^{\mathrm{B}}$ \\
$\mathrm{NC}+$ Phytase & $38.71^{\mathrm{B}}$ & $74.20^{\mathrm{A}}$ & $138.10^{\mathrm{A}}$ \\
$\mathrm{PC}+$ Phytase & $40.72^{\mathrm{A}}$ & $77.16^{\mathrm{A}}$ & $142.68^{\mathrm{A}}$ \\
\hline $\mathrm{SEM}^{3}$ & 1.44 & 2.89 & 6.16 \\
$\mathrm{p}$-value & $<0.0001$ & $<0.0001$ & 0.0059 \\
\hline
\end{tabular}

${ }^{1} \mathrm{PC}=$ positive control (diet meeting the nutritional requirements of the broiler chickens); ${ }^{2} \mathrm{NC}=$ negative control (reduction of 100 $\mathrm{kcal} / \mathrm{kg} \mathrm{ME}, 0.14 \%$ av $\mathrm{P}$ and $\left.0.11 \%{ }_{\mathrm{t}} \mathrm{Ca}\right) ;{ }^{3} \mathrm{SEM}=$ Standard error of the means. ${ }^{\mathrm{A}-\mathrm{B}}$ Different letters in the same column differ by the SNK test $(p<0.05)$.

Table 5. Means and standard error of total phosphorus released by bacterial phytase produced by Escherichia coli (RP), phosphorus bioavailability (PB), coefficient of variation (CV) and coefficient of determination $\left(\mathrm{R}^{2}\right)$ of broilers receiving 500 FTU phytase.

\begin{tabular}{lccccc}
\hline Variable & RP $(\mathbf{g})$ & PB $(\%)$ & CV $(\%)$ & $\mathbf{R}^{\mathbf{2}}$ & p-value \\
\hline BWG $(\mathrm{g})$ & $1.078 \pm 0.261$ & $0.090 \pm 0.020$ & 1.93 & 0.93 & $<0.0001$ \\
FCR $(\mathrm{g} / \mathrm{g})$ & $0.769 \pm 0.387$ & $0.070 \pm 0.031$ & 1.42 & 0.70 & 0.0007 \\
Ash $(\%)$ & $1.913 \pm 1.080$ & $0.160 \pm 0.090$ & 3.91 & 0.52 & 0.0082 \\
P $(\mathrm{mg} / \mathrm{g})$ & $1.384 \pm 0.755$ & $0.116 \pm 0.063$ & 4.14 & 0.60 & 0.0031 \\
\hline
\end{tabular}

$\mathrm{BWG}=$ body weight gain; FCR $=$ feed conversion ratio; $\mathrm{P}=$ phosphorus.

\section{Cost analysis}

One of the advantages of using phytase in the diet for broiler chickens is the financial aspect. Thus, an economic evaluation was carried out to quantify how much can be saved by reducing dicalcium phosphate and supplementing phytase, based on the results of $\mathrm{P}$ bioavailability. The body weight gain and tibia $P$ variables showed consistent values (with higher $\mathrm{R}^{2}$ ) for performance and bone parameters, respectively.
Considering the costs of the sources of inorganic phosphorus and phytase and the inclusion $(\mathrm{A}=\mathrm{U} \$$ $0.50 ; \mathrm{B}=\mathrm{U} \$ 6.00$ and $\mathrm{I}=0.1 \mathrm{~kg} / \mathrm{t}(500 \mathrm{FTU})$ ), it was possible to save US\$ 1.83 per ton of produced feed. In view of the expenses of the sources of inorganic phosphorus, phytase and the inclusion $(A=U \$ 0.50$; $\mathrm{B}=\mathrm{U} \$ 6.00$ and $\mathrm{I}=0.1 \mathrm{~kg} / \mathrm{t}(500 \mathrm{FTU}))$, it was possible to save US\$ 3.72 per ton of produced feed. 


\section{Discussion}

To check the efficiency of phytase used in diets with nutrient reduction on broiler performance, one must first prove that dietary reductions affect bird performance. Subsequently, the included phytase should be evaluated to determine the responses to the deficient diet and the diet that meets the requirement of the broilers. Nutrient reductions $\left(\mathrm{ME},{ }_{t} \mathrm{Ca}\right.$ and $\left.{ }_{\mathrm{av}} \mathrm{P}\right)$ in the negative control diet were significant for impairing broiler performance. Thus, it was possible to observe the responses to the use of Escherichia coli phytase on broiler performance. Broiler chickens fed deficient diets showed decreased feed intake and body weight gain. Reductions in ME are usually compensated by an increased in feed intake (LEESON et al., 1996; HAHN-DIDDE; PURDUM, 2014). However, the reduction of $\mathrm{P}$ acts in the opposite way, reducing the feed intake of broilers (VIVEIROS et al., 2002; LELIS et al., 2012; ROUSSEAU et al., 2012; LEE et al., 2017). When broilers are fed P-deficient diets, their serum concentrations of triiodothyronine (T3), tetraiodothyronine (T4) and growth hormone (GH) decrease (PARMER et al., 1987). In this sense, low levels of GH in P-deficient diets may be directly related to the development of the bird, since a bird that presents lower levels of this hormone will have its body weight gain reduced, which explains the lower feed intake.

Nutrient reductions in the negative control treatment also increased feed conversion ratio compared to the positive control diets. In this case, in addition to having a decline in their growth, the animals became less efficient in utilizing the diet. With the addition of the phytase, there was a significant improvement in feed conversion ratio, recovering some of the lost performance. Therefore, the Escherichia coli phytase was effective in releasing nutrients and improving performance. Adedokun et al. (2004), Dilger et al. (2004), Onyango et al. (2005) and Ribeiro Junior et al. (2016) showed a positive effect on body weight gain and feed intake with the inclusion of Escherichia coli phytase in diets with $\mathrm{P}$ reduction. Ahmad et al. (2000) and Rousseau et al. (2012) attributed the better performance of broilers fed diets with phytase inclusion to increased feed intake. In the current study, the improved performance of broiler chickens fed diets with phytase inclusion can be explained by their higher feed intake and also better digestibility.

Evaluating digestibility is essential to assess the efficiency of phytase on nutrient availability. The digestibility of $\mathrm{P}$ was $18.34 \%$ higher with the addition of Escherichia coli phytase, which elevated the bioavailability of $\mathrm{P}$, as shown in Table 5 . Thus, phytase was efficient in breakdown the phosphorusphytic acid complex, releasing minerals and making them available for absorption, increasing feed intake (SANTOS et al., 2008). The increase in feed intake seen in the negative control + phytase treatment resulted in a $8.84 \%$ higher body weight gain compared to negative control treatment, from 1 to 42 days. Other studies have also demonstrated greater body weight gain stemming from increased feed intake from the addition of phytase to the diet (COWIESON et al., 2011; LIU et al., 2014).

The Escherichia coli phytase supplemented without nutrient reduction was able to act on the phytate molecule, releasing the nutrients and improving the digestibility of crude protein, $\mathrm{Ca}$ and $\mathrm{P}$ compared to the positive control treatment. Thus, the positive control + phytase diet improved feed conversion ratio without affecting body weight gain compared to positive control treatment. According to Walk et al. (2014), improvements in feed conversion ratio may be attributed to the breakdown of phytate and to the utilization of inositol utilization phytase. Other studies have also shown that phytase inclusion in broiler diets improves the ileal digestibility of $\mathrm{P}$, amino acids, protein and ME (RUTHERFURD et al., 2004; SANTOS et al., 2008; COWIESON et al., 2017). Our results corroborate those presented by O'Connor-Dennie and Emmert (2012) who also observed an improvement in feed conversion ratio after adding phytase to P-deficient diets. However, Ahmad et al. (2000) reported increased body weight 
gain but no effects on the feed conversion ratio of broilers supplemented with phytase without nutrient reduction.

Phytase supplementation is more effective in $\mathrm{P}$-deficient diets than in P-sufficient diets for broilers (WATSON et al., 2006; KARIMI et al., 2011; SANTOS et al., 2013). This assertion was confirmed in the present study. In diets with reductions of $\mathrm{ME}, \mathrm{Ca}$ and ${ }_{\mathrm{av}} \mathrm{P}$ phytase promoted more benefits compared to its addition in the diet formulated according to the broiler's requirement. However, the inclusion of Escherichia coli phytase without nutrient reduction also proved to be efficient.

It is important to consider that regardless of how phytase is being used, an improvement in nutrient digestibility and bioavailability leads to decreased excretion to the environment, reducing soil and water contamination. The inclusion of Escherichia coli phytase in positive control diet improved the digestibility of $\mathrm{Ca}$, but it was higher when phytase was supplemented in negative control diet. Because the calculation of digestibility considers what has been consumed and not absorbed, its utilization efficiency may have been higher due to the nutrient reduction. In another hypothesis, suggested by De Kort et al. (2009), the formation of insoluble complexes between $\mathrm{Ca}$ and phosphate can be reduced by decreasing the concentration of $\mathrm{Ca}$, which would improve the digestibility of both minerals. Ravindran et al. (2008) observed an improvement in the digestibility of $\mathrm{Ca}$ and $\mathrm{P}$ in diets with microbial phytase. In the current study, phytase also improved the digestibility of these minerals when it was supplemented without nutrient reduction. With the inclusion of phytase in negative control diet, we noticed improvements in the digestibility of $\mathrm{P}$, but not for Ca. Sebastian et al. (1996) and Powell et al. (2011) also reported no increases in the digestibility of $\mathrm{Ca}$. It is known that one of the factors that influence the bioavailability of minerals are the interactions that occur between them(BREMNER; BEATTIE, 1995; COZZOLINO, 2007). Some authors have reported an increase in the apparent ileal digestibility of $\mathrm{P}$ by reducing the ${ }_{t} \mathrm{Ca}:{ }_{\mathrm{av}} \mathrm{P}$ ratio in broiler diets or simply reducing the concentrations of Ca (PLUMSTEAD et al., 2008; WALK et al., 2012a; ADEOLA; WALK, 2013). The significant increase in $\mathrm{P}$ digestibility resulting from the use of Escherichia coli phytase can be explained by the breakdown of the phytate structure, releasing molecules of P. Although there are other ions associated with the phytate molecules such as $\mathrm{Ca}$, $\mathrm{Mg}, \mathrm{Fe}$ and $\mathrm{Cu}$, their proportion is lower than the $\mathrm{P}$ molecules, which in turn reduces the ${ }_{t} \mathrm{Ca}$ av $\mathrm{P}$ ratio. Manangi and Coon (2008) observed that broilers have a better ability to utilize non-phytate $\mathrm{P}$ using a low ${ }_{t} \mathrm{Ca}$ : ${ }_{\mathrm{av}} \mathrm{P}$ ratio, due to an increase in endogenous phytase (APPLEGATE et al., 2003) or a reduction of dicalcium phosphate precipitation in the small intestine (WALK et al., 2012b).

Evaluating the efficacy of phytase on mineral deposition in the tibia is a measure of great relevance, because the bone tissue has the largest amount of these nutrients which can be used to determine its efficiency of utilization for deposition. In the current study, increased mineral availability and digestibility was evidenced by the ash, $\mathrm{Ca}$ and $\mathrm{P}$ content in the tibias of the broilers. According to Sakomura and Rostagno (2016), bone deposition should be the key item in the study of the efficacy of phytase, since the highest concentration of minerals is present in the bones of the animal. If the tibia is mineralized, this indicates that the mineral was available and used by the animal. The mineral $\mathrm{Ca}$ and $\mathrm{P}$ contents in the tibia are in line with the animal performance and diet digestibility results observed in our study.

The lowest levels of minerals found in the tibia of the broilers fed the negative control diets can be explained by the $\mathrm{P}$ deficiency, which reduces the rate of bone matrix formation and delays the onset of mineralization (BAYLINK et al., 1971). Parmer et al. (1987) evaluated low levels of P in broiler diets on bone parameters and found that P-deficient diets significantly reduced the amount of bone ash, as well as the length and width of the bone. 
The inclusion of Escherichia coli phytase in the negative control diet increased the concentration of ash, $\mathrm{Ca}$, and $\mathrm{P}$ in the bones, similarly to the result obtained with the positive control diet. Ahmad et al. (2000) also found similar values of ash, $\mathrm{Ca}$ and $\mathrm{P}$ in the tibias of broilers receiving treatments with reduced $\mathrm{Ca}$ and $\mathrm{P}$, using phytase, compared with treatments without nutrient reduction. Rutherfurd et al. (2012) reported an increase in the tibia ash content in broilers fed $\mathrm{P}$ reduced diets with phytase. O’Connor-Dennie and Emmert (2012) used phytase (500 FTU/kg) derived from Escherichia coli and found an increase in tibia ash and a $\mathrm{P}$ release of at least $0.083 \%$. Ribeiro Junior et al. (2016) supplemented diets with three levels (250, 500 and $1000 \mathrm{FTU} / \mathrm{kg}$ ) of Escherichia coli-derived phytase and observed of 80,103 , and $164 \%$ in tibia ash weight and 128, 198, and 330\% in tibia P content, respectively.

In an experiment with phytase inclusion without nutrient reduction, Ahmad et al. (2000) observed an increase in the concentration of all minerals compared to the control diet. This was not observed in the current study, where higher levels of ash were only obtained with the positive control treatment. However, according to Jiang et al. (2013), the mineral content in the tibia is closely related to the concentration of ${ }_{a v} \mathrm{P}$. Thus, phytase released the $\mathrm{P}$ present in the phytate molecule.

Escherichia coli phytase also improved P bioavailability. Based on the evaluated performance and bone-related variables, body weight gain and tibia $\mathrm{P}$ best represented the bioavailability. These were used to determine the economic viability. Although the bioavailability of $\mathrm{P}$ calculated from bone ash is the most widely used parameter, the bone $P$ variable showed a better fit. Although ash was not used in the calculations of economic viability in the current study, this parameter is correlated with the amount of $\mathrm{P}$ in the bones. Pillai et al. (2006) found an $\mathrm{R}^{2}$ of 0.72 and a bioavailability value of $0.16 \%$ for $\mathrm{P}$ calculated based on the tibia ash of broilers using phytase derived from Escherichia coli. In our study, we found the same results. Based on the bioavailability values of $0.090 \%$ for body weight gain and $0.116 \%$ for tibia $\mathrm{P}$, we determined the minimum cost of dicalcium phosphate $(\mathrm{kg})$ using phytase. If the price of dicalcium phosphate is higher than US\$0.12 and US\$0.10/kg, according to body weight gain and tibia $\mathrm{P}$, respectively, it is viable to use supplementation with Escherichia coli phytase.

\section{Conclusion}

Dietary supplementation with phytase produced from Escherichia coli for broiler chickens is recommended, as it increases the production performance, nutrient digestibility and energy metabolizability of those broilers and lowers the diet cost.

\section{Acknowledgments}

The authors thank the Pintaluba Group for the financial support.

\section{References}

ADEDOKUN, S. A.; SANDS, J. S.; ADEOLA, O. Determining the equivalent phosphorus released by an Escherichia coli-derived phytase in broiler chicks. Canadian Journal of Animal Science, Ottawa, v. 84, n. 3, p. 437-444, 2004.

ADEOLA, O. Phosphorus equivalency value of an Escherichia coli phytase in the diets of White Pekin ducks. Poultry Science, Champaign, v. 89, n. 6, p. 11991206, 2010.

ADEOLA, O.; COWIESON, A. J. Board-invited review: opportunities and challenges in using exogenous enzymes to improve non-ruminant animal production. Journal of Animal Science, Oxford, v. 89, n. 10, p. 3189-3218, 2011.

ADEOLA, O.; WALK, C. L. Linking ileal digestible phosphorus and bone mineralization in broiler chickens fed diets supplemented with phytase and highly soluble calcium. Poultry Science, Champaign, v. 92, n. 8, p. 2109-2117, 2013.

AHMAD, T.; RASOOL, S.; SARWAR, M.; HAQ, A.; HASAN, Z. Effect of microbial phytase produced from a 
fungus Aspergillus niger on bioavailability of phosphorus and calcium in broiler chickens. Animal Feed Science and Technology, Amsterdã, v. 83, n. 2, p. 103-114, 2000.

APPLEGATE, T. J.; ANGEL, R.; ClASSEN, H. L. Effect of dietary calcium, 25-hydroxycholecalciferol, or bird strain on small intestinal phytase activity in broiler chickens. Poultry Science, Champaign, v. 82, n. 7, p. 1140-1148, 2003.

AUGSPURGER, N. I.; WEBEL, D. M.; LEI, X. G.; BAKER, D. H. Efficacy of an E. coli phytase expressed in yeast for releasing phytate-bound phosphorus in young chicks and pigs. Journal of Animal Science, Oxford, v. 81, n. 2, p. 474-483, 2003.

BAYLINK, D.; WERGEDAL, J.; STAUFFER, M. Formation, mineralization and resorption of bone in hypophosphatemic rats. The Journal of Clinical Investigation, Ann Arbor, v. 50, n. 12, p. 2519-2530, 1971.

BREMNER, I.; BEATTIE, J. H. Copper and zinc metabolism in health and disease: speciation and interactions. The Proceedings of the Nutrition Society, Cambridge, v. 54, n. 2, p. 489-99, 1995.

COBB GUIDELINES. Broiler management guide. COBB 500. [S.1.]: [s.n.], 2012. 73 p. Available at: $<$ http://www.cobb-vantress.com/docs/default-source/ management-guides/broiler-management-guide.pdf $>$. Accessed at: 23 apr. 2014.

COUlibaly, A.; KOUAKOU, B.; CHEN, J. Phytic acid in cereal grains: structure, healthy or harmful ways to reduce phytic acid in cereal grains and their effects on nutritional quality. American Journal of Plant Nutrition and Fertilization Technology, Deira, v. 1, n. 1, p. 1-22, 2011.

COWIESON, A. J.; RUCKEBUSCH, J. P.; SORBARA, J. O.; WILSON, J. W.; GUGGENBUHL, P.; ROSS, F. F. A systematic view on the effect of phytase on ileal amino acid digestibility in broilers. Animal Feed Science and Technology, Amsterdã, v. 225, n. 3, p. 182-194, 2017.

COWIESON, A. J.; WILCOCK, P.; BEDFORD, M. R. Super-dosing effects of phytase in poultry and other monogastrics. World's Poultry Science Journal, Cambridge, v. 67, n. 2, p. 225-236, 2011.

COZZOLINO, S. M. F. Biodisponibilidade de nutrientes. 2. ed. São Paulo: Cozzolino, SMF, 2007. 992 p.

DE KORT, E.; MINOR, M.; SNOEREN, T.; VAN HOOIJDONK, T.; VAN DER LINDEN, E. Calciumbinding capacity of organic and inorganic ortho and polyphosphates. Dairy Science Technology, Paris, v. 89, n. 3-4, p. 283-299, 2009.
DILGER, R. N.; ONYANGO, E. M.; SANDS, J. S.; ADEOLA, O. Evaluation of microbial phytase in broiler diets. Poultry Science, Champaign, v. 83, n. 6, p. 962970, 2004.

GRAÑA, A.; TAVERNARI, F. C.; LELIS, G. R.; ALBINO, L. F. T.; ROSTAGNO, H. S.; GOMES, P. C. Evaluation of nutrient excretion and retention in broilers submitted to different nutritional strategies. Revista Brasileira de Ciência Avícola, Campinas, v. 15, n. 2, p. 161-168, 2013.

HAHN-DIDDE, D.; PURDUM, S. E. The effects of an enzyme complex in moderate and low nutrient-dense diets with dried distillers grains with solubles in layhing hens. Journal of Applied Poultry Research, Oxford, v. 23, n. 1, p. 23-33, 2014.

JIANG, X.; LUO, F.; QU, M.; BONTEMPO, V.; WU, S.; ZHANG, H.; YUE, H.; QI, G. Effect of non-phytate phosphorus levels and phytase sources on the growth performance, serum biochemical and tibial parameters of broiler chickens. Italian Journal of Animal Science, Viterbo, v. 12, n. 3, p. 375-380, 2013.

KARIMI, A.; BEDFORD, M. R.; SADEGHI, G. H.; GHOBADI, Z. Influence of dietary non-phytate phosphorus levels and phytase supplementation on the performance and bone characteristics of broilers. Revista Brasileira de Ciência Avícola, Campinas, v. 13, n. 1, p. 43-51, 2011.

LEE, S. A.; NAGALAKSHIMI, D.; RAJU, M. V. L. N.; RAO, S. V. R.; BEDFORD, M. R. Effect of phytase superdosing myo-inositol and available phosphorus concentrations on performance and bone mineralization in broilers. Animal Nutrition, Beijing, v. 3, n. 3, p. 247251, 2017.

LEESON, S.; CASTON, L.; SUMMERS, J. D. Broiler response to diet energy. Poultry Science, Champaign, v. 75, n. 4, p. 529-535, 1996.

LELIS, G. R.; ALBINO, L. F. T.; CALDERANO, A. A.; TAVERNARI, F. C.; ROSTAGNO, H. S.; CAMPOS, A. M. A.; ARAÚJO, W. A. G.; RIBEIRO JÚNIOR, V. Diet supplementation with phytase on performance of broiler chickens. Revista Brasileira de Zootecnia, Viçosa, MG, v. 41, n. 4, p. 929-933, 2012.

LIU, S. Y.; CADOGAN, D. J.; PÉRON, A.; TRUONG, H. H.; SELLE, P. H. Effects of phytase supplementation on growth performance, nutrient utilization and digestive dynamics of starch and protein in broiler chickens offered maize, sorghum and wheat based diets. Animal Feed Science and Technology, Amsterdã, v. 197, p. 164175, 2014. 
MANANGI, M. K.; COON, C. N. Phytate phosphorus hydrolysis in broilers in response to dietary phytase, calcium, and phosphorus concentrations. Poultry Science, Champaign, v. 87, n. 8, p. 1577-1586, 2008.

NELSON, D. L.; COX, M. M. Princípios de bioquímica de Lehninger. 6. ed. Porto Alegre: Nelson, DL, 2014. $1336 \mathrm{p}$.

O'CONNOR-DENNIE, T.; EMMERT, J. The effect of phytase source, wheat middlings, and citric acid on phosphorus utilization, growth performance, and carcass yield in broilers. Tropical Agriculture, Saint Augustine, v. 89 , n. 4, p. 240-251, 2012.

ONYANGO, E. M.; BEDFORD, M. R.; ADEOLA, O. Efficacy of an evolved Escherichia coli phytase in diets of broiler chicks. Poultry Science, Champaign, v. 84, n. 2, p. 248-255, 2005.

PANDEY, A.; SZAKACS, G.; SOCCOL, C. R.; RODRIGUEZ-LEON, J. A.; SOCCOL, V. T. Production, purification and properties of microbial phytases. Bioresource Technology, Amsterdã, v. 77, n. 3, p. 203214, 2001.

PARMER, T. G.; CAREW, L. B.; ALSTER, F. A. Thyroid function, growth hormone, and organ growth in broilers deficient in phosphorus. Poultry Science, Champaign, v. 66, n. 12, p. 1995- 2004, 1987.

PILLAI, P. B.; O'CONNOR-DENNIE, T.; OWENS, C. M.; EMMERT, J. L. Efficacy of an Escherichia coli phytase in broilers fed adequate or reduced phosphorus diets and its effect on carcass characteristics. Poultry Science, Champaign, v. 85, n. 10, p. 1737-1745, 2006.

PLUMSTEAD, P. W.; LEYTEM, A. B.; MAGUIRE, R. O.; SPEARS, J. W.; KWANYUEN, P.; BRAKE, J. Interaction of calcium and phytate in broiler diets: effects on apparent pre cecal digestibility and retention of phosphorus. Poultry Science, Champaign, v. 87, n. 3, p. 449-458, 2008.

POWELL, S.; BIDNER, T. D.; SOUTHERN, L. L. Phytase supplementation improved growth performance and bone characteristics in broilers fed varying levels of dietary calcium. Poultry Science, Champaign, v. 90, n. 3, p. 604-608, 2011.

RAGGON, M.; AUMELAS, A.; CHEMARDIN, P.; GALVEZ, S.; MOULIN, G.; BOZE, H. Complete hydrolysis of myo-inositol hexakisphosphate by a novel phytase from Debaryomyces castelli CBS 2923. Applied Microbiology and Biotechnology, New York, v. 78, n. 1, p. 47-53, 2008.

RAVINDRAN, V.; CABAHUG, S.; RAVINDRAN, G.; BRYDEN, W. Influence of microbial phytase on apparent ileal amino acid digestibility of feeds tuffs for broilers.
Poultry Science, Champaign, v. 78, n. 5, p. 699-706, 1999.

RAVINDRAN, V.; COWIESON, A. J.; SELLE, P. H. Influence of dietary electrolyte balance and microbial phytase on growth performance, nutrient utilization, and excreta quality of broiler chickens. Poultry Science, Champaign, v. 87, n. 4, p. 677-688, 2008.

RIBEIRO JUNIOR, V.; SALGUERO, S. C.; GOMES, G.; BARROS, V. R. S. M.; SILVA, D. L.; BARRETO, S. L. T.; ROSTAGNO, H. S.; HANNAS, M. I.; ALBINO, L. F. T. Efficacy and phosphorus equivalency values of two bacterial phytases (Escherichia coli and Citrobacter braakii) allow the partial reduction of dicalcium phosphate added to the diets of broiler chickens from 1 to 21 days of age. Animal Feed Science and Technology, Amsterdã, v. 221, Part A, p. 226-233, 2016.

ROSTAGNO, H. S.; ALBINO, L. F. T.; DONZELE, J. L.; GOMES, P. C.; OLIVEIRA, R. F. M.; LOPES, D. C.; FERREIRA, A. S.; BARRETO, S. L. T.; EUCLIDES, R. F. Tabelas brasileiras para aves e suínos: composição de alimentos e exigências nutricionais. 3. ed. Viçosa, MG: Rostagno, HS, 2011. 252 p.

ROUSSEAU, X.; LÉTOURNEAU-MONTMINY, M. P.; MÊME, N.; MAGNIN, M.; NYS, Y.; NARCY, A. Phosphorus utilization in finishing broiler chickens: effects of dietary calcium and microbial phytase. Poultry Science, Champaign, v. 91, n. 11, p. 2829-2837, 2012.

RUTHERFURD, S. M.; CHUNG, T. K.; MOREL, P. C. H.; MOUGHAN, P. J. Effect of microbial phytase on ileal digestibility of phytate phosphorus, total phosphorus, and amino acids in a low-phosphorus diet for broilers. Poultry Science, Champaign, v. 83, n. 1, p. 61-68, 2004.

RUTHERFURD, S. M.; CHUNG, T. K.; THOMAS, D. V.; ZOU, M. L.; MOUGHAN, P. J. Effect of a novel phytase on growth performance, apparent metabolizable energy, and the availability of minerals and amino acids in a low-phosphorus corn-soybean meal diet for broilers. Poultry Science, Champaign, v. 91, n. 5, p. 1118-1127, 2012.

SAKOMURA, N. K.; ROSTAGNO, H. S. Métodos de pesquisa em nutrição de monogástricos. 2. ed. Jaboticabal: Sakomura, NK, 2016. 262 p.

SANTOS, F. R.; HRUBY, M.; PIERSON, E. E. M.; REMUS, J. C.; SAKOMURA, N. K. Effect of phytase supplementation in diets on nutrient digestibility and performance in broiler chicks. Journal of Applied Poultry Research, Oxford, v. 17, n. 2, p. 191-201, 2008.

SANTOS, T. T.; SRINONGKOTE, S.; BEDFORD, M. R.; WALK, C. L. Effect of high phytase inclusion rates on performance of broilers fed diets not severely limited 
in available phosphorus. Asian-Australian Journal of Animal Sciences, Seoul, v. 26, n. 2, p. 227-232, 2013.

SEBASTIAN, S.; TOUCHBURN, S. P.; CHÁVEZ, E. R. Implications of phytic acid and supplemental microbial phytase in poultry nutrition: a review. World's Poultry Science Journal, Cambridge, v. 54, n. 1, p. 27-47, 1998.

SEBASTIAN, S.; TOUCHBURN, S. P.; CHÁVEZ, E. R.; LAGUE, P. C. Efficacy of supplemental microbial phytase at different dietary calcium levels on growth performance and mineral utilization of broiler chicks. Poultry Science, Champaign, v. 75, n. 12, p. 1516-1523, 1996.

SELLE, P. H.; RAVINDRAN, V. Microbial phytase in poultry nutrition. Animal Feed Science and Technology, Amsterdã, v. 135, n. 1-2, p. 1-41, 2007.

SILVA, J. D.; QUEIROZ, A. C. Análise de alimentos: métodos químicos e biológicos. 2. ed. Viçosa, MG: Silva JD, 2009. $235 \mathrm{p}$.

SOHAIL, S. S.; ROLAND, D. A. Influence of supplemental phytase on performance of broilers from four to six weeks of age. Poultry Science, Champaign, v. 78, n. 4, p. 550-558, 1999.

STATISTICAL ANALYSIS SYSTEM INSTITUTE SAS. SAS/STAT® 9.0 User's guide. Cary: SAS Institute Inc., 2002.

VIVEIROS, A.; BRENES, A.; ARIJA, I.; CENTENO, C. Effects of microbial phytase supplementation on mineral utilization and serum enzyme activities in broiler chicks fed different levels of phosphorus. Poultry Science, Champaign, v. 81, n. 8, p. 1172-1183, 2002.
WALDROUP, P. W.; KERSEY, J. H.; SALEH, E. A.; FRITTS, C. A.; YAN, F.; STILBORN, H. L.; CRUM, R. C.; RABOY, V. Nonphytate phosphorus requirement and phosphorus excretion of broiler chicks fed diets composed of normal or high available phosphate corn with and without microbial phytase. Poultry Science, Champaign, v. 79, n. 10, p. 1451-1459, 2000.

WALK, C. L.; ADDO-CHIDIE, E. K.; BEDFORD, M. R.; ADEOLA, O. Evaluation of a highly soluble calcium source and phytase in the diets of broiler chickens. Poultry Science, Champaign, v. 91, n. 9, p. 2255-2263, 2012a.

WALK, C. L.; BEDFORD, M. R.; MCELROY, A. P. In vitro evaluation of limestone, dicalcium phosphate, and phytase on calcium and phosphorus solubility of corn and soybean meal. Poultry Science, Champaign, v. 91, n. 3, p. 674-682, 2012b.

WALK, C. L.; SANTOS, T. T.; BEDFORD, M. R. Influence of superdoses of a novel microbial phytase on growth performance, tibia ash, and gizzard phytate and inositol in young broilers. Poultry Science, Champaign, v. 93, n. 5, p. 1172-1177, 2014.

WATSON, B. C.; MATHEWS, J. O.; SOUTHERN, L. L.; SHELTON, J. L. The effects of phytase on growth performance and intestinal transit time of broilers fed nutritionally adequate diets and diets deficient in calcium and phosphorus. Poultry Science, Champaign, v. 85, n. 3, p. 493-497, 2006. 